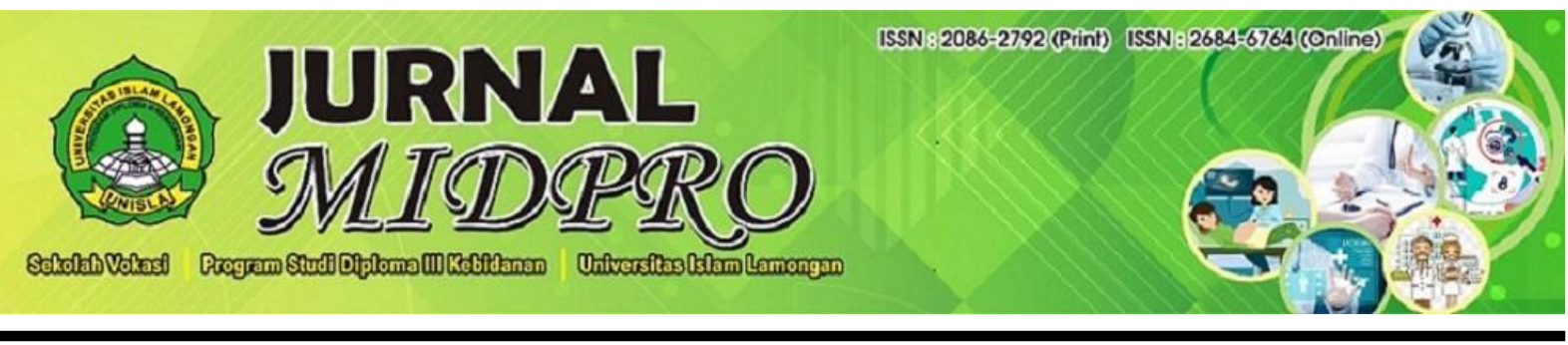

\title{
Relationship between Training Intensity and Doctor's Job Satisfaction at Primary Health Care in Indonesian
}

\author{
${ }_{\text {Kita Purnamasari }}{ }^{1}$, Misnaniarti ${ }^{2}$ \\ ${ }^{1}$ Magister Program of Public Health Science, Faculty of Public Health, Sriwijaya University \\ ${ }^{2}$ Public Health, Sriwijaya University \\ Email Penulis Korespondensi $\left({ }^{\mathrm{K}}\right)$ : gitapurnamasari82@gmail.com
}

\begin{abstract}
A doctor's job satisfaction is important because it will improve the quality of health services. This study aimed to determine the relationship between intensity training and doctors satisfaction. This research was a cross-sectional study using data from Risnakes 2017. The sample was 5,140 doctors primary health care with civil servant status in Indonesia that was randomly selected. The data were analyzed using the Spearman correlation. This study showed that mean job satisfaction was 70.07 and intensity of the training was 3.98. There is a positive correlation between the training intensityand the doctor's job satisfaction of primary health care in Indonesia ( $p$-value $<0.000$ and $\mathrm{r}=0.063$ ). More doctor's training will improve the ability of doctors to care for the patient's clinical according to the standards of competence.
\end{abstract}

Keywords: Doctor; training intensity; job satisfaction

\section{Article history :}

Received: 17 Juni 2020

Received in revised form: 10 September 2020

Accepted: 15 October 2020

Available online: 1 December 2020 


\section{INTRODUCTION}

Job satisfaction is an important aspect that is often discussed in human resources management because of using controlling employee's job satisfaction so that organization leadership (either executive or supervisor) can maximize its employees to reach organization goals. ${ }^{1}$ According to Robbins (2008), job satisfaction is a positive feeling for a job that results from evaluating several characteristics. Positive and negative feelings about work will have an impact on worker satisfaction or dissatisfaction. Job satisfaction is positive, if the job performance is greater than expectations, and if the job performance is less than expectations, then job satisfaction is negative. ${ }^{2}$

Job satisfaction has a relationship with several variables including performance, organizational commitment, customer satisfaction, frequenting / absence, and employee turnover. Job satisfaction is a predictor of performance because job satisfaction has a moderate correlation with performance. Job satisfaction also has a positive and strong influence on organizational commitment. Job satisfaction will also increase customer satisfaction because customer perceptions will increase along with the increase in organizational profitability. It was found that there was a consistent relationship between job satisfaction and absenteeism/absence, although at moderate and weak levels. And also found a relationship between job satisfaction and employee turnover (turnover), where the relationship between job satisfaction and employee turnover is stronger than job satisfaction and absenteeism. ${ }^{3}$

According to Herzberg (1959), a person's job satisfaction is influenced by intrinsic and extrinsic factors. Intrinsic factors are factors related to work that arises from within employees, which include promotion, self-development, recognition, responsibility, and achievement. Meanwhile, extrinsic factors are related to factors around the work that originate outside of the worker, such as supervision, salaries, and incentives, job security, working conditions, and policies. ${ }^{4}$

A doctor's job satisfaction is an important thing in health services because a doctor's job satisfaction will affect the quality of health services and patient satisfaction. ${ }^{5}$ One of the government's First Level Health Facilities (FKTP) that organizes first-level public and individual health efforts with affordable access to villages and remote areas is primary health care. ${ }^{6}$ Therefore, the job satisfaction of doctors at primary health care is very important for improving the health services facility on giving services.

One of the self-development for employees that affects job satisfaction is training. Training for employees is defined as the process of improving work skills, both technical and managerial skills that focus on direct practice and its implementation in a short time. ${ }^{7}$ According to government regulations number 11 (2017) Regarding the management of Civil Servants (PNS), there are many various forms of training can be provided to PNS employees, such as training, seminars, courses, upgrades, learning, workplace guidance, distance training, internships, and exchanges between civil servants and employees. private. ${ }^{8}$

Many studies have shown that there was a relationship between training and job satisfaction for the health worker. As well the study by Yami et all (2011), that getting a result that less training causes 
the inability of health workers to use their skills in carrying out their jobs, thereby reducing the level of job satisfaction. ${ }^{9}$ Therefore the writer would like to know the relationship between the training intensityand doctors job at primary health care in Indonesia.

\section{METHODS}

This study used a qualitative method by cross-sectional design. The data that was used in this study from the 2017 Workforce Research in the Health Sector (Risnakes 2017) by the National Institute of Health Research and Development, Indonesian Ministry of Health. The scope of the study covers 9.699 primary health care in Indonesia. The data collected from Risnakes 2017 was done by an enumerator at primary health care. The subject of this study was the doctors who participate as Risnakes 2017 respondents chosen by simple random sampling. The inclusion criteria in this study were the doctors with civil servants or civil servants candidate staffing, with their exclusion criteria was the missing data and irrelevant to the respondents. The clear sample that was used by 3.780 people by the elected sample sequences.

The dependent variable in this study was job satisfaction that is the number of job satisfaction scores measured by using the Minnesota Satisfaction Questionnaire (MSQ) scale. Whereas the independent variable was training intensity obtained by doctors from early 2016 until the research was conducted. The data were analyzed with univariate and bivariate by using SPSS software $\mathrm{p}<0,05$ significant level and 95\% confidence interval. Univariate analysis is like descriptive frequency distribution. Bivariate analysis in this study is using spearman correlation test.

\section{RESULTS}

Based on table 1. it can be seen that most of the respondents (70.12\%) were women. Most of the respondents were 30-39 years old (51.61\%) and 40-49 years old (31.25\%). Almost all respondents (93.35\%) are currently married or have been married. A total of $75.31 \%$ of respondents were functional staff and only $24.69 \%$ were heads of primary health care. As many as $89.22 \%$ of respondents are new employees with a working period of under 10 years. The regions of Java and Bali are the regions with the highest percentage of doctors, namely $52.00 \%$. 


\begin{tabular}{|c|c|c|}
\hline Variable & $\mathrm{N}$ & $\%$ \\
\hline \multicolumn{3}{|l|}{ Gender } \\
\hline Women & 3,604 & 70.12 \\
\hline Male & 1,536 & 29.88 \\
\hline \multicolumn{3}{|l|}{ Age } \\
\hline$\geq 50$ years & 497 & 9.67 \\
\hline 40 - 49 years & 1,606 & 31.25 \\
\hline $30-39$ years & 2,653 & 51.61 \\
\hline$<30$ years & 384 & 7.47 \\
\hline \multicolumn{3}{|l|}{ Marital Status } \\
\hline Single & 342 & 6.65 \\
\hline Marry & 4,798 & 93.35 \\
\hline \multicolumn{3}{|l|}{ Position } \\
\hline $\begin{array}{l}\text { Head of } \\
\text { primary health } \\
\text { care }\end{array}$ & 1,269 & 24.69 \\
\hline $\begin{array}{l}\text { Functional } \\
\text { staff }\end{array}$ & 3871 & 75.31 \\
\hline \multicolumn{3}{|l|}{ Years of service } \\
\hline$>10$ years & 554 & 10.78 \\
\hline$\leq 10$ years & 4,586 & 89.22 \\
\hline \multicolumn{3}{|l|}{ Work Area } \\
\hline \multicolumn{3}{|l|}{ Region } \\
\hline Java and Bali & 2,673 & 52.00 \\
\hline Sumatra & 1,321 & 25.73 \\
\hline Sulawesi & 503 & 9.79 \\
\hline Borneo & 419 & 8.15 \\
\hline Nusa & & \\
\hline $\begin{array}{l}\text { Tenggara, } \\
\text { Maluku and } \\
\text { Papua }\end{array}$ & 224 & 4.36 \\
\hline
\end{tabular}

Based on table 2, it can be seen that the average training intensity attended by doctors in the 20162017 period was 3.98 times, with a standard deviation of 2.51 times. Doctors receive at least 2 training times and a maximum of 16 times. Job satisfaction score of 70.07, with a standard deviation of 9.11. The minimum job satisfaction score is 30 and the maximum score is 100 .

Table 2. Distribution of Training Intensity and Job Satisfaction

\begin{tabular}{lcccc}
\hline \multicolumn{1}{c}{ Variable } & Mean & SD & $\begin{array}{c}\text { Min / } \\
\text { Max }\end{array}$ & $p$ \\
\hline Training & 3.98 & 2.5 & $2 /$ & 0,000 \\
Intensity & & 1 & 16 & \\
\hline Job & 70.07 & 9,1 & $30 /$ & 0,000 \\
satisfaction & & 1 & 100 & \\
\hline
\end{tabular}

Based on table 3 it can be seen that $51.79 \%$ of the doctors were satisfied with their work, while $48.21 \%$ were dissatisfied with their work. 
The results of normality testing carried out on the variable training intensity and job satisfaction are shown in table 2 , the $\mathrm{p}$-value is 0.000 ( $\mathrm{p}$-value $<0.05$ ). This indicates that the data is not normally distributed so that the bivariate analysis used is the Spearman correlation.

Table 3. Distribution of Job Satisfaction Frequency

\begin{tabular}{lrl}
\hline \multicolumn{1}{c}{ Job satisfaction } & \multicolumn{1}{l}{$\mathrm{n}$} & \multicolumn{1}{l}{$\%$} \\
\hline Satisfied & 2,662 & 51.79 \\
\hline Not satisfied & 2,478 & 48.21 \\
\hline
\end{tabular}

Based on table 4, it can be seen that the Spearman correlation results show that there is a significant and positive patterned relationship between training intensity and job satisfaction with a pvalue $=0.000$, although the strength of the relationship is on a weak scale $(\mathrm{R}<0.25)$.

Table 4. Correlation of Training Intensity and Job Satisfaction

\begin{tabular}{ccc}
\hline Variable & $\mathbf{R}$ & $\boldsymbol{p}$-value \\
\hline Training Intensity & 0.063 & 0,000 \\
\hline
\end{tabular}

\section{DISCUSSION}

The result of the data analysis showed that there was a relationship between training intensity and doctors' job satisfaction in Indonesia. It was such as with the study by Ahmad and Al-Borie (2012) on 250 doctors representing all teaching hospitals in Saudi Arabia. Where the results of the study state that training and development are one of the factors that influence the job satisfaction of doctors at teaching hospitals in Saudi Arabia. Training and development are also factors that have a positive impact on physicians' performance. ${ }^{10}$

Employee training is an assessment that will be a driving factor to increase employee job satisfaction. Because training is a process of teaching certain knowledge and skills and attitudes so that employees are more skilled and able to carry out their responsibilities better and by standards. The impact of training on employee job satisfaction will increase if the training materials delivered are preceded by an initial evaluation of what matters are technically still a major obstacle among employees. ${ }^{11}$

In an era of technological change and the rapid development of science, training is very important to maintain employee productivity. This shows the potential that training has to increase employee job satisfaction. The quality of training will affect job satisfaction in general and in particular, will improve employee performance. Training will provide knowledge and skills for employees to do work effectively. ${ }^{12}$

For doctors, training is something important because training is one of the points of the Continuing Professional Development and Education (P2KB) program. P2KB itself aims to improve the 
professionalism of each doctor by assessing his personal ability (self-assessment) to plan competency development through the fulfillment of a minimum credit score to obtain a certificate of competence as a primary health care doctor. A competency certificate is a requirement for applying for an extension of the Practice License (SIP). Therefore, training is needed by a doctor in fulfilling competence as a doctor. $^{13}$

For primary health care doctors, the training provided is adjusted to the competence of abilities clinical level 4, which is the competency standard for general practitioners in primary health care, such as the ability to detect and explain clinical symptoms of the disease and determine appropriate referrals. The second ability is to diagnose the disease clinically and determine the appropriate referral for the patient. The third ability is being able to make diagnosis, preliminary therapy, and make referrals in both non-emergency and emergency cases. While the fourth ability is to make a diagnosis, complete preliminary therapy, and the same as the completion of treatment. ${ }^{14}$

According to the health minister's decision, there are 124 disease diagnoses can be handled by doctors at the primary health care. Determination of diseases that enter 124 diagnoses is based on diseases with a high incidence rate in the community, diseases with a high-risk level in the community, and requiring expensive medical costs. ${ }^{15}$ The results of the training will further increase job satisfaction if the training provided to doctors is by the competency capabilities and also the disease standards that must be handled by doctors at the primary health care.

The data used in this study are the results of a survey collected with the help of enumerators from all over Indonesia, so there is a high probability that data entry errors will occur. so the researchers did data cleaning

\section{CONCLUSION AND SUGGESTION}

The results showed that there was a positive relationship between the intensity of training received by doctors and the doctor's job satisfaction. As it is hoped public health office in a rural or urban area can improve training implementation frequency for doctors at primary health care. As it is hoped public health office in a rural or urban area can improve training implementation frequency for doctors at primary health care.

\section{ACKNOWLEDGMENT}

We want to say thanks to the National Institute of Health Research and Development, Indonesian Ministry of Health that has permitted us to use data from Risnakes 2017.

\section{REFERENCES}

1. Sedarmayanti. Manajemen Sumber Daya Manusia Reformasi Birokrasi dan Manajemen Pegawai Negeri Sipil. Bandung: PT Refika Aditama; 2013.

2. Busro M. Teori-Teori Manajemen Sumber Daya Manusia. Edisi 1. Jakarta: Prenadamedia Group; 
2018.

3. Wibowo. Perilaku dalam Organisasi. Edisi 1. Jakarta: Rajawali Pers; 2013.

4. Bangun W. Manajemen Sumber Daya Manusia. Jakarta: Penerbit Erlangga; 2012.

5. Mrduljas-Dujie, Natasa K, Marion K, Goran R, Mirjana. Job satisfaction among medical doctors in one of the countries in transition: Experience from Croatia. Coll Antropol. 2010;34(3):813-8.

6. Permenkes No 43. Peraturan Menteri Keseharan Republik Indonesia Nomor 43 Tahun 2019 Tentang Pusat Kesehatan Masyarakat. Kementerian Kesehatan Republik Indonesia; 2019.

7. Hasibuan M. Manajemen Sumber Daya Manusia. edisi rev. Jakarta: Bumi Aksara; 2017.

8. Peraturan Pemerintah No 11. Peraturan Pemerintah Republik Indonesia Nomor 11 tahun 2017 tentang Manajemen Pegawai Negeri Sipil. Pemerintah Republik Indonesia; 2017.

9. Yami A, Hamza L, Hassen A, Jira C, Sudhakar M. Job Satisfaction and Its Determinants Among Health Workers In Specialized Hospital, Southwest Ethiopia. Ethiop J Health Sci. 2011;21(August):19-27.

10. Ahmad AMK, Al-Borie HM. Impact of Internal Marketing on Job Satisfaction and Organizational Commitment : A Study of Teaching Hospitals in Saudi Arabia. Bus Manag Res. 2012;1(3):82-94.

11. Supatmi ME, Nimran U, Utami HN. Pengaruh Pelatihan, Kompensasi terhadap Kepuasan Kerja Karyawan dan Kinerja Karyawan. Profit J Adm Bisnis. 2013;7(1):25-37.

12. Leppel K, Brucker E, Psyd JC. The Importance of Job Training to Job Satisfaction of Older Workers. J Aging Soc Policy. 2012;24(1):62-76.

13. PB IDI. Petunjuk Teknis Program Pengembangan Pendidikan Keprofesian Berkelanjutan (P2KB) bagi Dokter Edisi II. Jakarta: Pengurus Besar Ikatan Dokter Indonesia; 2015.

14. Perkonsil No 11. Peraturan Konsil Kedokteran Indonesia Nomor 11 Tahun 2012 Tentang Standar Kompetensi Dokter Indonesia. Konsil Kedokteran Indonesia; 2012.

15. Kepmenkes No. 514. Keputusan Menteri Kesehatan Republik Indonesia Nomor HK.02.02/Menkes/514/2015 Tentang Panduan Praktik Klinis Bagi Dokter di Fasilitas Pelayanan Kesehatan Tingkat Pertama. Kementrian Kesehatan Republik Indonesia; 2015. 